\title{
Meta-Analysis of Bismuth Quadruple Therapy versus Clarithromycin Triple Therapy for Empiric Primary Treatment of Helicobacter pylori Infection
}

\author{
Marino Venerito ${ }^{a}$ Tina Krieger $^{b}$ Thomas Ecker ${ }^{b}$ Gioacchino Leandro ${ }^{c}$ \\ Peter Malfertheiner ${ }^{\mathrm{a}}$ \\ a Department of Gastroenterology, Hepatology and Infectious Diseases, Otto-von-Guericke University, Magdeburg, \\ and ${ }^{b}$ Ecker + Ecker GmbH, Hamburg, Germany; ' Gastroenterology Unit 1, Gastroenterological Hospital 'S. De Bellis' \\ IRCCS, Castellana Grotte, Italy
}

\section{Key Words}

Helicobacter pylori · Quadruple therapy · Triple therapy .

Antibiotic resistance

\begin{abstract}
Background: In areas with high clarithromycin resistance, bismuth quadruple therapy (BQT) is recommended instead of clarithromycin triple therapy (CTT) as the first-line treatment for Helicobacter pylori eradication. Methods: Randomized clinical trials (RCTs) comparing BQT to CTT were identified through electronic and manual searches. A meta-analysis was performed to compare the efficacy and tolerability of these two regimens as first-line treatments for $H$. pylori infection. The effect of antibiotic resistance on treatment efficacy was also analyzed. Results: Twelve RCTs were included. BQT achieved eradication in $77.6 \%$ of patients, whereas CTT achieved an eradication rate of $68.9 \%$ [risk difference $(\mathrm{RD})=$ $0.06,95 \% \mathrm{Cl}:-0.01 / 0.13]$. A high heterogeneity among the trials was found $\left(x^{2}=50.16, p<0.00001 ; l^{2}=78 \%\right)$. In the subgroup analysis for treatment duration, the 10-day BQT was more effective than the 7-day CTT (RD $=0.25,95 \%$ $\mathrm{Cl}$ : 0.18/0.32), whereas no differences were observed between $\mathrm{CTT}$ and BQT given for 7 or 10 days. There were no
\end{abstract}

\section{KARGER}

E-Mail karger@karger.com

www.karger.com/dig statistical differences in side effects and compliance between both therapies (RD $=0.92,95 \% \mathrm{Cl}: 0.76 / 1.12$, and $\mathrm{RD}=-0.03,95 \% \mathrm{Cl}:-0.05 / 0.00$, respectively). The effect of antibiotic resistance on eradication rates was reported in 4 of the 12 RCTs. Clarithromycin resistance significantly affected the efficacy of $C T$ ( $R D=0.75,95 \% \mathrm{Cl}: 0.63 / 0.87$ ), whereas $\mathrm{BQT}$ efficacy was not affected by metronidazole resistance $(\mathrm{RD}=0.09,95 \% \mathrm{Cl}:-0.06 / 0.25)$. Conclusions: The 10-day BQT was more effective than the 7-day CTT as a first-line therapy for $H$. pylori infection, whereas BQT and CTT for 7 or 10 days yielded similar eradication rates. Compliance and side effect rates were similar for both therapies. BQT overcomes clarithromycin resistance and its efficacy is not affected by metronidazole resistance.

Copyright $\odot 2013$ S. Karger AG, Basel

\section{Introduction}

Helicobacter pylori infection is still one of the world's most frequent infections and accounts for high morbidity and mortality. About $20 \%$ of subjects infected with the bacterium will develop complications of the infection including peptic ulcer disease and gastric cancer, which ac-
(C) 2013 S. Karger AG, Basel

0012-2823/13/0881-0033\$38.00/0
Prof. Peter Malfertheiner, MD

Klinik für Gastroenterologie, Hepatologie und Infektiologie Otto-von-Guericke Universität

Leipziger Strasse 44, DE-39120 Magdeburg (Germany)

E-Mail peter.malfertheiner@med.ovgu.de 
counts for at least 738,000 deaths annually [1]. Given the high prevalence and serious health burden of $H$. pylori infection, it is crucial to use a highly effective and welltolerated eradication regimen.

The recent Maastricht IV consensus conference recommends for first-line empirical treatment of $H$. pylori infection a combination of a proton pump inhibitor (PPI), clarithromycin, and amoxicillin or metronidazole [clarithromycin triple therapy (CTT)] for 7-14 days in areas of low clarithromycin resistance and a combination of a PPI, bismuth, metronidazole, and tetracycline [bismuth quadruple therapy (BQT)] for 10-14 days in areas of clarithromycin resistance $>15-20 \%$ [2]. The rationale for these recommendations is the increasing clarithromycin resistance rate in Europe and other geographical regions $[3,4]$. Two previous meta-analyses on the effect of CTT and BQT found similar eradication rates for both regimens when used as first-line therapies for $H$. pylori infection. Compliance and side effects were similar for both therapy regimens as well $[5,6]$. In the present metaanalysis, we further evaluated and compared the efficacy and tolerability of BQT and CTT by including recent trials. We included the analysis on the effect of resistance to clarithromycin and metronidazole on the efficacy of treatments.

\section{Methods}

Data Sources and Search Strategy

To find relevant articles for this review, a search of MEDLINE, EMBASE, and the Cochrane Library for randomized clinical trials (RCTs) published between 1995 and November 2011 was carried out. Only the following search terms were used: 'Helicobacter $p y$ lori', 'triple therapy', 'quadruple therapy', 'amoxicillin', 'clarithromycin', 'bismuth', 'metronidazole', 'tetracycline', and 'eradication'. No limits for language were entered for the search. Boolean operators ('AND', 'OR', 'NOT') were used to narrow and widen the search results. The titles from the search results were examined closely and determined to be suitable for potential inclusion into the study. In addition, the references from selected articles were examined as a further search tool.

\section{Study Selection}

For inclusion in the meta-analysis, a study had to meet the following criteria: (1) randomized clinical trial; (2) treatment with BQT (metronidazole, bismuth-containing compound, tetracycline, and PPI) versus CTT (amoxicillin, clarithromycin, and PPI) as the first-line therapy for eradication of $H$. pylori infection; (3) method of $H$. pylori diagnosis by urea breath test, rapid urease test, histology, and/or fecal antigen testing; (4) main outcome measure as an intention-to-treat (ITT) eradication rate, and (5) eradication testing with urea breath test and/or histology at least 4 weeks after completion of therapy.

\section{Data Extraction}

Only RCTs were included in our analysis. Using a predefined meta-analysis form, two independent reviewers (M.V. and T.K.) extracted data from each study. This process resulted in high interobserver agreement $(\mathrm{k}=0.91)$. Information contained the names of the authors, title of the study, journal in which the study was published, country and year of the study, treatment regimen, dosage, length of the therapy, method by which $H$. pylori infection was diagnosed and method of eradication, testing sample size (with sex differentiation if applicable), the number of patients receiving each regimen and within the group the number of patients who succeeded and the number of patients who failed to eradicate the $H$. pylori infection, the number of patients who were compliant and the number of patients who were not compliant in each group, and the number of patients reporting side effects and the number of patients with no side effects in each arm. In studies where susceptibility tests for clarithromycin and metronidazole in $H$. pylori strains were performed, the number of eradicated subjects with resistant and sensitive strains was collected. After completing the data extraction, the two independent reviewers discussed the results and, if discrepancies were present, a consensus was reached.

\section{Data Synthesis and Analysis}

Study outcomes for the meta-analysis included the following: (1) eradication rate of BQT compared with CTT reported as ITT, (2) compliance rate of BQT versus CTT, (3) incidence of side effects associated with BQT versus CTT, and (4) the effect of resistance to clarithromycin and metronidazole on the efficacy of treatments. Risk difference (RD), which represents the difference between the frequency of the events in the two groups (quadruple therapy and triple therapy), was used to calculate the pooled effect of BQT versus CTT. A 95\% confidence interval (95\% CI) was calculated using both a fixed-effects model and a random-effects model. The test for funnel plot asymmetry was carried out. To assess whether the variation in the effects of treatment across trials was greater than might be expected, a statistical evaluation of heterogeneity by $\chi^{2}$ test was used. Heterogeneity was considered to be present if the $\chi^{2}$ test delivered a $\mathrm{p}<0.05$. An $I^{2}$ statistic was used to quantify the proportion of total variation in the study estimate due to heterogeneity. Any heterogeneity identified would prompt subgroup analysis on the basis of random-effects models in attempt to explain these findings. For subgroups with considerable heterogeneity, meta-regression for the year of publication was performed. The regression coefficients $(\mathrm{r})$ for the meta-regression analysis were reported. An $r$ value $>0.7$ was considered relevant. Furthermore, the cumulative effect over time was analyzed using statistical software [7]. This same method was applied to assess compliance rates and the incidence of adverse events between the two study groups. All computations and plots were carried out with metaanalysis software [7].

\section{Results}

\section{Description of Included Studies}

The initial search strategy identified a total of 89 potential articles for inclusion. After detailed review of selected articles, 12 RCTs [8-19] with 2,753 patients ful- 
Fig. 1. Flow diagram of studies identified in

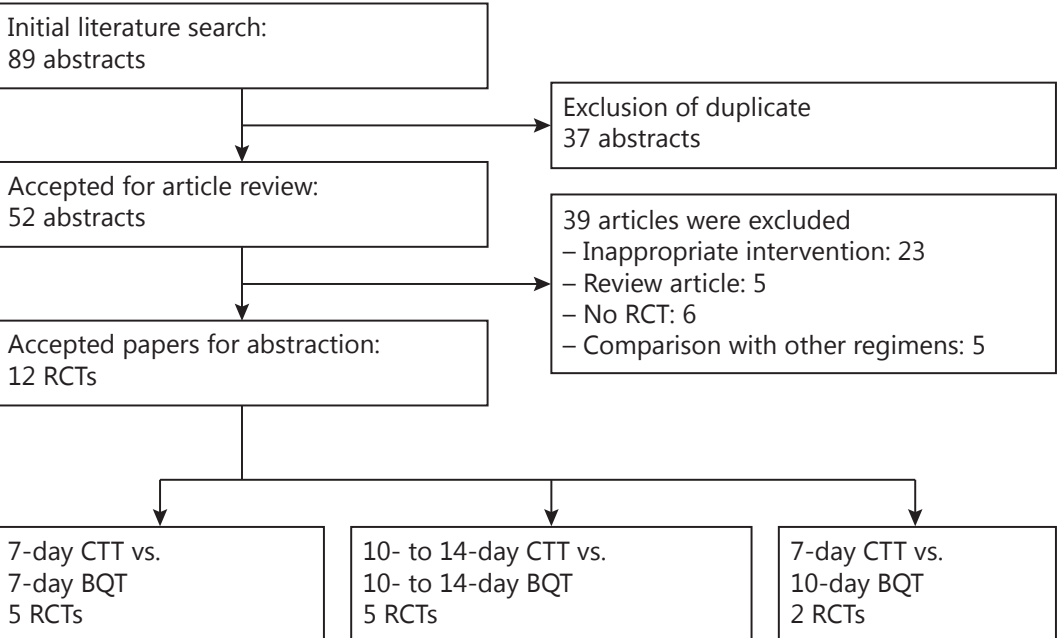
the systematic review and meta-analysis.

filled the inclusion criteria of the meta-analysis (fig. 1). The most common reasons for exclusion from the metaanalysis included treatment regimens offered as secondline treatment and regimens composed of medications inconsistent with traditional CTT or BQT. Tables 1, 2 and Appendix table 1 summarize the characteristics of the included studies. Antibiotic dosing regimens for triple therapy were quite consistent among trials (clarithromycin $1,000 \mathrm{mg} /$ day, amoxicillin 2,000 mg/day), but varied considerably for quadruple therapy (bismuth 240-1,680 $\mathrm{mg}$ /day, metronidazole $400-1,500 \mathrm{mg} /$ day, tetracycline $1,500-2,000 \mathrm{mg} /$ day).

\section{Meta-Analysis of ITT Eradication Rates}

In the meta-analysis of ITT eradication rates of the 12 included studies (Appendix fig. 1) the quadruple therapy achieved an eradication rate of $77.6 \%$, whereas the eradication rate with triple therapy was $68.9 \%(\mathrm{RD}=0.06,95 \%$ CI: -0.01/0.13). There was no evidence to suggest significant publication bias according to the test for asymmetry of the funnel plot (Appendix fig. 2). Our analysis did have high heterogeneity $\left(\chi^{2}=50.16, \mathrm{p}<0.00001 ; I^{2}=78 \%\right)$. In an attempt to explain heterogeneity, we conducted subgroup analyses (table 3 ).

\section{Subgroup Analysis for Duration of Treatment}

Regimens

The different durations of the treatment regimens ( 7 , 10 , or 14 days for each regimen in different combinations) best explains the high heterogeneity among the

Quadruple vs. Triple Therapy for

H. pylori Eradication studies. Therefore, we stratified trials in 3 subgroups according to the duration of treatment regimens $(\mathrm{A}=7$ days for both groups; $\mathrm{B}=10-14$ days for both groups; $\mathrm{C}=7$ days for triple therapy and 10 days for quadruple therapy; fig. 1,2). No differences were observed between the two therapy regimens in subgroup A. Heterogeneity within group B was still high. When only trials with 10 days of treatment for both regimens were considered [11-13], summation of individual studies was possible. There were also no significant differences observed between the two therapy regimens in this subanalysis. In the sensitivity analysis of group C, BQT achieved eradication in $82.5 \%$ of patients, whereas triple therapy achieved an eradication rate of $57.7 \%(\mathrm{RD}=0.25,95 \% \mathrm{CI}: 0.18 / 0.32$ ).

\section{Subgroup Analysis for Year of Publication}

The year of publication of the single studies may also represent a source of heterogeneity. The meta-regression analysis for year of publication showed a significant relationship between year of publication and efficacy of therapy regimen ( $r=0.88$, data not shown). In the subanalysis per year of publication comparing studies published between 2000 and 2005 versus studies published between 2006 and 2011, BQT was more effective than CTT within studies conducted in the period 2006-2011, but comparable to CTT within studies conducted in 2000-2005 (table 3). Heterogeneity was negligible within the group of studies published between 2000 and 2005, and moderate within the groups with a more recent year of publication (2006-2011). 
Table 1. Year, location, therapy regimens, and treatment duration of the studies

\begin{tabular}{|c|c|c|c|c|c|c|}
\hline Author & Year & Location & Triple therapy & Quadruple therapy & \multicolumn{2}{|c|}{ Treatment duration, days } \\
\hline $\begin{array}{l}\text { Katelaris } \\
\text { et al. [10] }\end{array}$ & 2002 & $\begin{array}{l}\text { Australia/ } \\
\text { New Zeeland }\end{array}$ & $\begin{array}{l}\text { pantoprazole } 40 \mathrm{mg} \text {, b.i.d. } \\
\text { amoxicillin } 1 \mathrm{~g} \text {, b.i.d. } \\
\text { clarithromycin } 500 \mathrm{mg} \text {, b.i.d. }\end{array}$ & $\begin{array}{l}\text { pantoprazole } 40 \mathrm{mg} \text {, b.i.d. } \\
\text { tetracycline } 500 \mathrm{mg} \text {, q.i.d. } \\
\text { metronidazole } 200 \mathrm{mg} \text {, t.i.d. } / 400 \mathrm{mg} \text { q.h.s. } \\
\text { bismuth subcitrate } 108 \mathrm{mg} \text {, q.i.d. }\end{array}$ & 7 & 7 \\
\hline $\begin{array}{l}\text { Laine } \\
\text { et al. [12] }\end{array}$ & 2003 & $\begin{array}{l}\text { United States/ } \\
\text { Canada }\end{array}$ & $\begin{array}{l}\text { omeprazole } 20 \mathrm{mg} \text {, b.i.d. } \\
\text { amoxicillin } 1 \mathrm{~g} \text {, b.i.d. } \\
\text { clarithromycin } 500 \mathrm{mg} \text {, b.i.d. }\end{array}$ & $\begin{array}{l}\text { omeprazole } 20 \mathrm{mg} \text {, b.i.d. } \\
\text { tetracycline } 375 \mathrm{mg} \text {, q.i.d. }{ }^{1} \\
\text { metronidazole } 375 \mathrm{mg} \text {, q.i.d. }{ }^{1} \\
\text { bismuth biskalcitrate } 420 \mathrm{mg} \text {, q.i.d. }{ }^{1}\end{array}$ & 10 & 10 \\
\hline $\begin{array}{l}\text { Pai } \\
\text { et al. [13] }\end{array}$ & 2003 & India & $\begin{array}{l}\text { lansoprazole } 30 \mathrm{mg} \text {, b.i.d. } \\
\text { amoxicillin } 500 \mathrm{mg} \text {, q.i.d. } \\
\text { clarithromycin } 500 \mathrm{mg} \text {, b.i.d. }\end{array}$ & $\begin{array}{l}\text { lansoprazole } 30 \mathrm{mg} \text {, b.i.d. } \\
\text { tetracycline } 500 \mathrm{mg} \text {, q.i.d. } \\
\text { metronidazole } 400 \mathrm{mg} \text {, t.i.d. } \\
\text { tripotassium dicitrato bismuthate } 120 \mathrm{mg} \text {, q.i.d. }\end{array}$ & 10 & 10 \\
\hline $\begin{array}{l}\text { Jang } \\
\text { et al. [14] }\end{array}$ & 2005 & Korea & $\begin{array}{l}\text { PPI, b.i.d. } \\
\text { amoxicillin } 1 \text { g, b.i.d. } \\
\text { clarithromycin } 500 \mathrm{mg} \text {, b.i.d. }\end{array}$ & $\begin{array}{l}\text { PPI, b.i.d. } \\
\text { tetracycline } 500 \mathrm{mg} \text {, q.i.d. } \\
\text { metronidazole } 500 \mathrm{mg} \text {, t.i.d. } \\
\text { bismuth subcitrate } 300 \mathrm{mg} \text {, q.i.d. }\end{array}$ & 7 & 7 \\
\hline $\begin{array}{l}\text { Songür } \\
\text { et al. [17] }\end{array}$ & 2009 & Turkey & $\begin{array}{l}\text { lansoprazole } 30 \mathrm{mg} \text {, b.i.d. } \\
\text { amoxicillin } 1 \text { g, b.i.d. } \\
\text { clarithromycin } 500 \mathrm{mg} \text {, b.i.d. }\end{array}$ & $\begin{array}{l}\text { lansoprazole } 30 \mathrm{mg} \text {, b.i.d. } \\
\text { tetracycline } 500 \mathrm{mg} \text {, q.i.d. } \\
\text { metronidazole } 500 \mathrm{mg} \text {, t.i.d. } \\
\text { bismuth subcitrate } 300 \mathrm{mg} \text {, q.i.d. }\end{array}$ & 14 & 10 \\
\hline $\begin{array}{l}\text { Zheng } \\
\text { et al. [18] }\end{array}$ & 2010 & China & $\begin{array}{l}\text { pantoprazole } 40 \mathrm{mg} \text {, b.i.d. } \\
\text { amoxicillin } 1 \mathrm{~g} \text {, b.i.d. } \\
\text { clarithromycin } 500 \mathrm{mg} \text {, b.i.d. }\end{array}$ & $\begin{array}{l}\text { pantoprazole } 40 \mathrm{mg} \text {, b.i.d. } \\
\text { tetracycline } 750 \mathrm{mg} \text {, b.i.d. } \\
\text { metronidazole } 400 \mathrm{mg} \text {, t.i.d. } \\
\text { bismuth subcitrate } 220 \mathrm{mg} \text {, b.i.d. }\end{array}$ & 7 & 10 \\
\hline $\begin{array}{l}\text { Malfertheiner } \\
\text { et al. [19] }\end{array}$ & 2011 & $\begin{array}{l}\text { France, Germany, } \\
\text { Ireland, Italy, } \\
\text { Poland, Spain, UK }\end{array}$ & $\begin{array}{l}\text { omeprazole } 20 \mathrm{mg} \text {, b.i.d. } \\
\text { amoxicillin } 1 \text { g, b.i.d. } \\
\text { clarithromycin } 500 \mathrm{mg} \text {, b.i.d. }\end{array}$ & 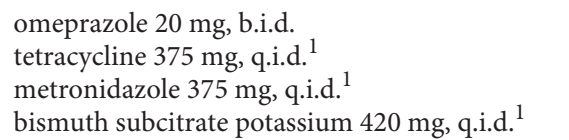 & 7 & 10 \\
\hline
\end{tabular}

b.i.d. = Twice a day; t.i.d. = three times a day; q.i.d. = four times a day; q.h.s. = nightly. ${ }^{1}$ The quadruple therapy consisted of three single-triple capsules, each containing $140 \mathrm{mg}$ of the reported bismuth salt, metronidazole $125 \mathrm{mg}$, and tetracycline $125 \mathrm{mg}$, given q.i.d. plus one omeprazole 20 -mg capsule b.i.d. 
Table 2. Study results

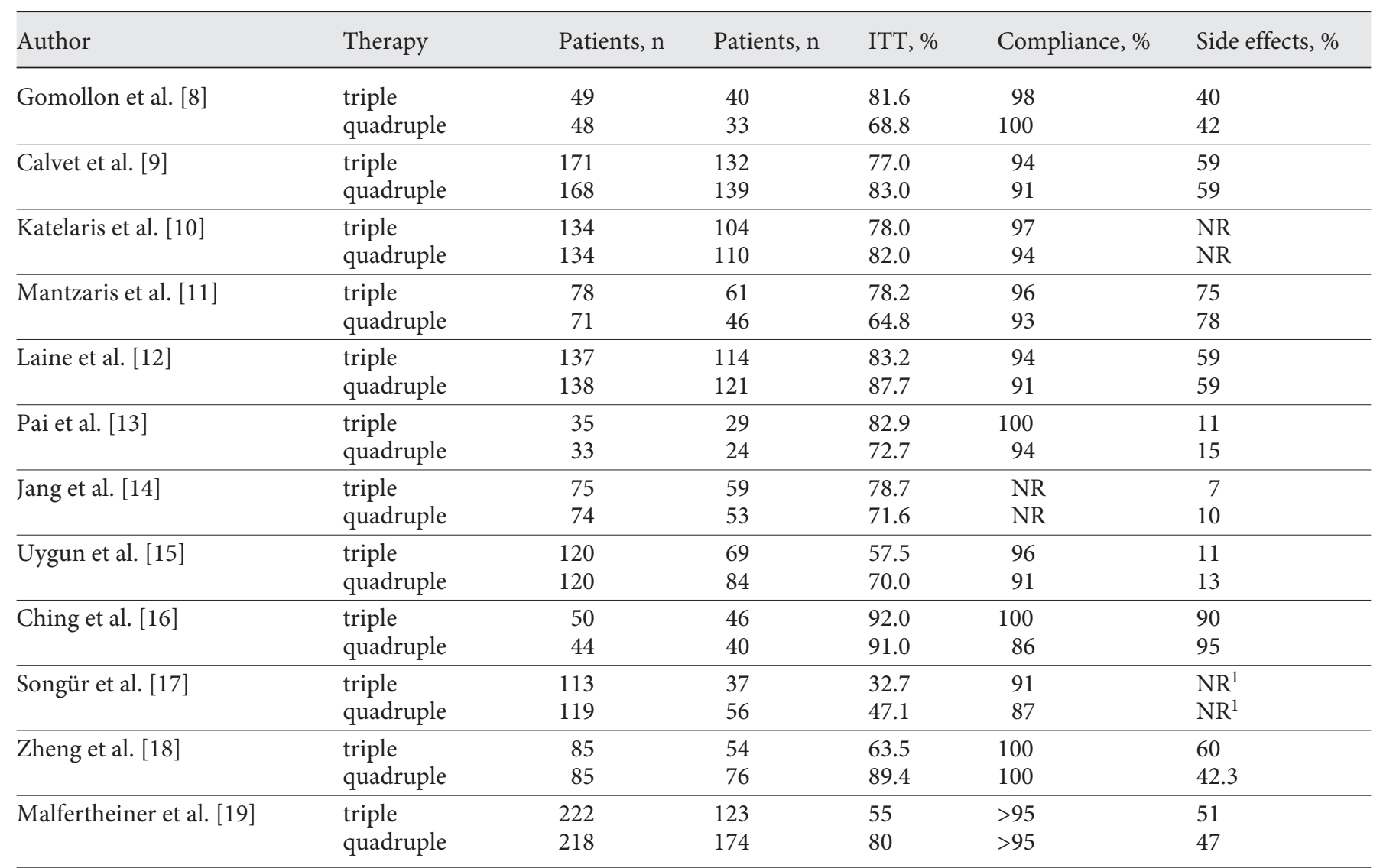

$\mathrm{NR}=$ Not reported. ${ }^{1}$ Frequency of single side effects was reported, but the percentage of patients presenting side effects was not.

Table 3. Subgroup analyses

\begin{tabular}{|c|c|c|c|c|c|c|c|}
\hline & $\begin{array}{l}\text { Partici- } \\
\text { pants } \\
\text { n }\end{array}$ & $\begin{array}{l}\text { Studies } \\
\mathrm{n}\end{array}$ & $\begin{array}{l}\text { Eradication } \\
\text { rate with } \\
\text { CTT, \% }\end{array}$ & $\begin{array}{l}\text { Eradication } \\
\text { rate with } \\
\text { BQT, \% }\end{array}$ & $\mathrm{RD}(95 \% \mathrm{CI})$ & $\mathrm{p}$ & $\begin{array}{l}I^{2} \\
\text { statis- } \\
\text { tic }^{2}, \%\end{array}$ \\
\hline Duration: 7 days for both arms $[8-10,14,16]$ & 798 & 4 & 79.3 & 80.6 & $0.01(-0.05 / 0.08)$ & 0.2 & - \\
\hline Duration: 10 days for both arms [11-13] & 492 & 3 & 81.6 & 78.9 & $-0.048(0.08 /-0.18)$ & 0.069 & - \\
\hline Duration: 7 days for CTT and 10 days for BQT $[18,19]$ & 610 & 2 & 57.6 & 82.5 & $0.25(0.18 / 0.32)$ & 0.84 & - \\
\hline Location: Eastern hemisphere $[10,11,13-15,17,18]^{1}$ & 1,296 & 7 & 65.6 & 72.5 & $0.05(0.16 /-0.06)$ & $<0.00001$ & 82.2 \\
\hline Location Western hemisphere $[8,9,12,16]^{1}$ & 804 & 4 & 81.3 & 84.2 & $0.03(0.09 /-0.03)$ & 0.245 & 49.6 \\
\hline Dyspeptic symptoms $[16,17,19]$ & 766 & 3 & 54.5 & 74.7 & $0.16(0.29 / 0.04)$ & 0.02 & 87.3 \\
\hline Nonulcer dyspepsia $[10,15,18]$ & 678 & 3 & 67.4 & 80.0 & $0.14(0.26 / 0.01)$ & 0.025 & 86.4 \\
\hline Active peptic ulcer $[8,9,11,13,14]$ & 721 & 5 & 78.7 & 78.9 & $-0.06(0.03 /-0.15)$ & 1.00 & 61.6 \\
\hline
\end{tabular}

Eradication rate reported as ITT. ${ }^{1}$ Spain and UK were considered as part of the Western hemisphere because the largest part of these countries is in the Western hemisphere. ${ }^{2} I^{2}$ statistic is reported only in the presence of heterogeneity (i.e. $\chi^{2}$ delivered a $p<0.05$ ). 


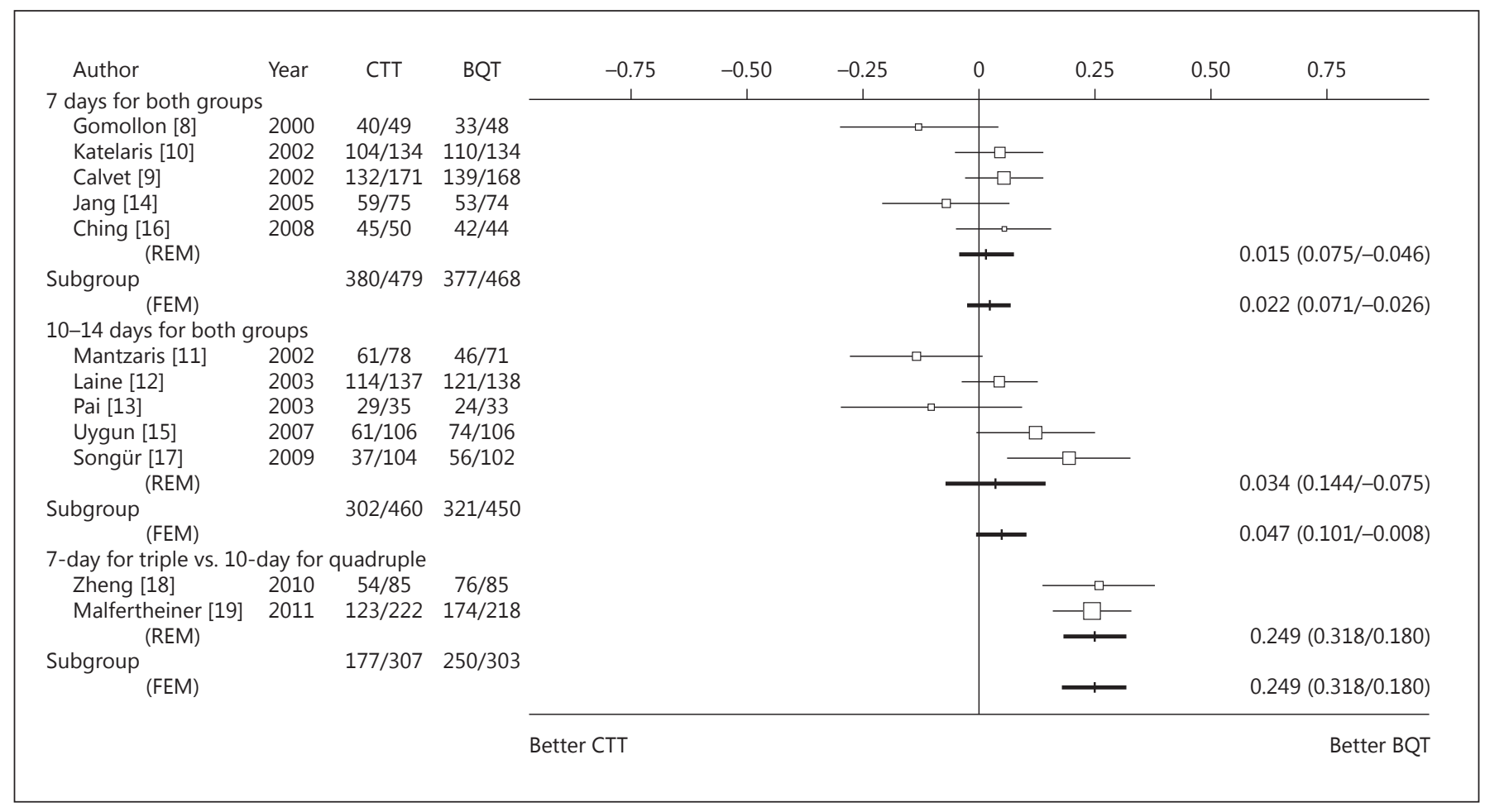

Fig. 2. Forest plot of BQT vs. CTT: subgroup analysis according to the duration of treatment regimens. RD with 95\% CI is shown on the right side of the figure. REM = Random-effects model; FEM = fixed-effects model.

Subgroup Analysis for Study Location

Study location may also represent a source of heterogeneity and different antimicrobial resistance rates between the Western and Eastern hemispheres may have an impact on treatment outcomes. Our analysis showed no significant differences in eradication rates between BQT and CTT in studies conducted in the Western hemisphere (Appendix fig. 3, table 3). In the subanalysis of ITT eradication rates of the 7 studies conducted in the Eastern hemisphere, the BQT achieved an eradication rate of $72.5 \%$, whereas the eradication rate with CTT was $65.6 \%$ $(\mathrm{RD}=0.052,95 \% \mathrm{CI}:-0.06 / 0.16)$. Heterogeneity within the Eastern hemisphere group exceeded our baseline results. In an attempt to explain heterogeneity within this subgroup, a meta-regression analysis for year of publication and frequency of eradication was performed, and showed a significant correlation for both variables $(r=0.88$ and -0.75 , respectively, data not shown). Thus, again the heterogeneity in this subgroup can be partially explained by the decreasing efficacy of CTT over the years. In studies conducted in 2006-2011 in the Eastern hemisphere, CTT achieved an eradication rate of $51.5 \%$ compared with $78.6 \%$ in studies conducted in 2000-2005 (data not shown). Furthermore, in the Eastern hemisphere, BQT achieved an ITT eradication rate of $70.3 \%$ in studies conducted in 2006-2011, whereas in studies conducted in $2000-2005$, an ITT eradication rate of $74.7 \%$ was achieved (data not shown).

Influence of Local Clarithromycin Resistance on

Efficacy of Therapy Regimens

Local clarithromycin resistance rates may influence the efficacy of both therapy regimens. Therefore, available data on local clarithromycin resistance in the countries of the included trials were collected and a meta-regression analysis for local clarithromycin resistance was performed. The available data on local clarithromycin resistance are as follows: Spain 14\% [4], Australia/New Zealand 8\% [10], Greece 24.7\% [4], India 4.7\% [20], United States/Canada $11 \%$ [13], Korea 10.8\% [21], Turkey 48.2\% [22], United Kingdom 9\% [4], and China 20.8\% [18]. The meta-regression analysis for local clarithromycin resistance showed no influence of local clarithromycin resistance rates on the efficacy of either therapy regimen $(r=0.17)$.
38

Digestion 2013;88:33-45

DOI: $10.1159 / 000350719$
Venerito/Krieger/Ecker/Leandro/ Malfertheiner 


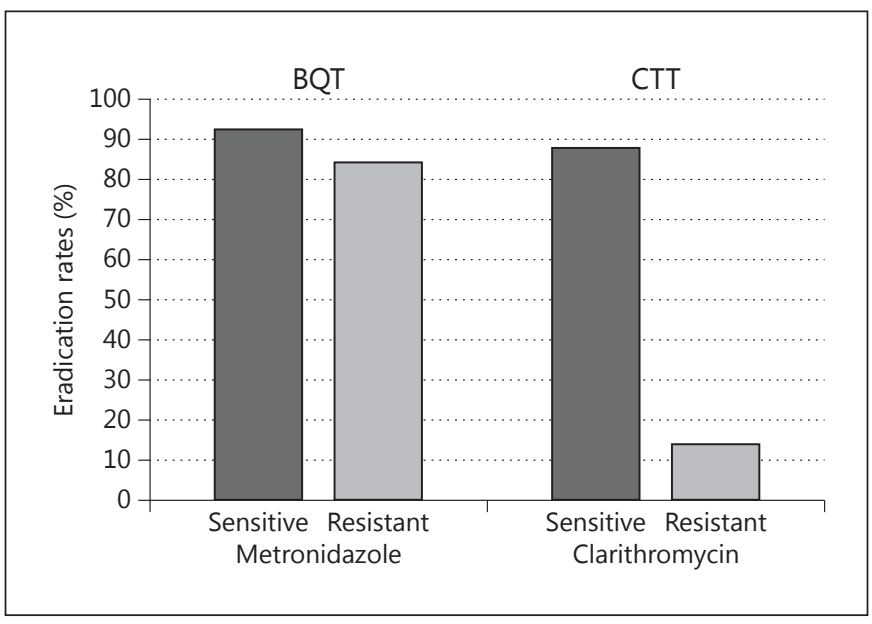

Fig. 3. ITT eradication rates achieved by BQT and CTT based on metronidazole and clarithromycin resistance, respectively (data derived from Katelaris et al. [9], Laine et al. [13], Zheng et al. [18], and Malfertheiner et al. [19]).

Subgroup Analysis according to Treatment

Populations

The failure rate of $H$. pylori eradication has been reported to be significantly lower in patients with duodenal ulcer than in patients with nonulcer dyspepsia [18]. Therefore, we further stratified studies according to treatment populations, i.e. studies investigating $H$. pylori eradication rates in patients with dyspeptic symptoms, nonulcer dyspepsia, and active peptic ulcer (table 3, Appendix figure 4). BQT was more effective than CTT for $H$. pylori eradication in patients with dyspeptic symptoms and nonulcer dyspepsia, yet within both groups we found significant heterogeneity. Our analysis did not find any significant difference between BQT and CTT in patients with peptic ulcer disease, yet within this group no heterogeneity was found.

\section{Meta-Analysis of Compliance and Side Effects}

Eleven out of the 12 studies [8-13,15-19] included data on compliance rates (table 2). Acceptable compliance was differently defined and varied from 75 to $100 \%$ of completed therapy. Overall, the compliance rate was 92 and 96\% with BQT and CTT, respectively. There was a statistically significant difference between the two groups $(\mathrm{RD}=$ $-0.03,95 \%$ CI: $-0.05 / 0.00)$. Heterogeneity was not present.

All but two of the included studies $[10,17]$ describe the incidence of side effects within each group. The overall incidence of side effects in patients receiving BQT and CTT was 46 and $46.3 \%$, respectively (table 2 ). There were no statistically significant differences in side effects yielded by each group. Heterogeneity was not present.

\section{Role of Antibiotic Resistance}

Four out of 12 studies $[10,12,18,19]$ also assessed the effect of antimicrobial susceptibility on eradication rates. ITT eradication rates achieved by quadruple and triple therapies based on metronidazole and clarithromycin resistance are shown in figure 3. Clarithromycin resistance significantly affected the efficacy of triple therapy $(\mathrm{RD}=$ 0.75, 95\% CI: 0.63/0.87). Indeed, CTT achieved eradication in $88 \%$ of clarithromycin-sensitive strains and in $14.3 \%$ of clarithromycin-resistant strains. However, metronidazole resistance did not affect the efficacy of quadruple therapy. Indeed, BQT achieved eradication in $92 \%$ of metronidazole-sensitive strains and $84.2 \%$ of metronidazole-resistant strains. The role of simultaneous susceptibility for metronidazole and clarithromycin was tested in 2 of the 12 studies $[18,19]$. In the presence of simultaneous metronidazole and clarithromycin resistance, BQT was superior to CTT for eradication of $H$. pylori infection $(\mathrm{RD}=26.52,95 \% \mathrm{CI}: 3.43 / 205.06$, data not shown). Given the small number of patients with simultaneous metronidazole and clarithromycin resistance (14 in the group receiving BQT and 17 in the group receiving CTT) included, these results should be interpreted cautiously.

\section{Discussion}

In our meta-analysis, CTT and BQT given both for 7 or 10 days yielded similar eradication rates when used as a first-line therapy for eradication of $H$. pylori infection. Furthermore, no difference in compliance rate or incidence of treatment-associated side effects between BQT and CTT was found. The results of our updated metaanalysis at first glance are consistent with those from two previous meta-analyses that compared these treatment regimens $[5,6]$. However, in the subgroup analysis of treatment duration, the 10-day BQT was shown to be more effective than the 7-day CTT. The comparison of two different treatment durations may raise criticism of our analysis. To rebut this point, a recent meta-analysis reported that a treatment with CTT beyond 7 days would confer only a slight benefit of about $5 \%$ in eradication efficacy if the treatment is extended to 14 days [23]. Furthermore, if this analysis is restricted to the four highestquality trials as assessed by the Jadad scale [24], prolongation of CTT beyond 7 days (with extension up to 10 days) was not associated with an additional benefit. This has 
been confirmed in a recent randomized trial in patients infected with $H$. pylori without an increase in eradication efficacy if CTT was extended up to 14 days [25]. Clarithromycin resistance obviously cannot be overcome by increasing the dose or duration of therapy [26]. Regarding BQT, a 10- to 14-day treatment is recommended by international guidelines [27-29]. A recent survey in Europe reported that the $H$. pylori resistance rate for metronidazole is as high as $34.9 \%$ [4]. Unlike clarithromycin, metronidazole resistance can to a great extent be overcome by increasing the duration of therapy and the dose of metronidazole, which should not be lower than 1,500 mg [30]. Indeed, a meta-analysis of 91 treatment arms concluded that if nitroimidazole resistance is present, a nitroimidazole-containing regimen should be avoided or a quadruple regimen should be given for $>1$ week' [31]. On the basis of these data, a first-line empirical $H$. pylori treatment with BQT given for 10 days or longer is expected to work.

The strongest predictor of $H$. pylori treatment failure appears to be antimicrobial resistance [32]. Clarithromycin resistance is the most important clinically because resistance cannot be overcome by increasing the dose or duration of therapy. Amoxicillin and tetracycline resistance instead is negligible as resistance for these two antibiotics is reported to be very low $(<1 \%)$ in most countries $[4,32]$. In our analysis CTT achieved eradication in $88 \%$ of clarithromycin-sensitive strains but only in $14.3 \%$ of clarithromycin-resistant strains. Furthermore, the meta-regression analysis for year of publication showed a decreasing efficacy of triple therapy over years, mostly due to increasing clarithromycin resistance. With few exceptions worldwide, the prevalence of clarithromycin resistance has increased to a level where CTT is no longer effective $[4,32]$. Thus, in the future, a clinical trial comparing a candidate effective first-line $H$. pylori therapy with CTT can no longer be considered ethical in countries with a high rate of clarithromycin resistance. On the contrary, BQT achieved an ITT-eradication rate as high as $92 \%$ in metronidazole-sensitive strains and $84.2 \%$ in metronidazole-resistant strains. Thus, BQT is effective even in cases with proven metronidazole resistance in vitro and represents a good treatment option for empirical first- and second-line $H$. pylori eradication therapy.

In patients with dyspeptic symptoms and nonulcer dyspepsia, BQT was more effective than CTT for $H$. $p y$ lori eradication. A higher resistance rate to clarithromycin reported in nonulcer dyspeptic patients in comparison to duodenal ulcer patients is likely to account for this [33].
In patients with peptic ulcer disease, BQT and CTT yielded similar eradication rates as a first-line treatment for $H$. pylori infection. The lower prevalence of $H$. pylori strains with clarithromycin resistance among patients with peptic ulcer disease accounts for the similar eradication rates between the CTT and the BQT in this specific group of patients. A lower prevalence of clarithromycin resistance among patients with peptic ulcer disease was described previously [4], but remains unexplained.

\section{Strengths and Limitations}

To minimize bias, two authors selected the studies and extracted the data; this process resulted in high interobserver agreement $(\mathrm{k}=0.91)$. The presence of publication bias was excluded by both graphical and statistical evaluation. All studies included in the analysis were RCTs. Our literature research was not restricted to English-language reports. We were able to extract data from each study, regardless of the language, with the exception of the exclusion criteria from the article by Jang et al. [14], which was published in Korean.

When considering the results of this meta-analysis, potential limitations should be considered. Heterogeneity was present and could not be accounted for by multiple subgroup analyses. Further, individual studies included in our analysis differed in several respects. Indeed, studies defined varying inclusion and exclusion criteria and used different PPIs. Relevant to BQT, antibiotic dosing regimens and bismuth formulations varied considerably among trials. The heterogeneity in the regimens included in this analysis could have affected eradication rates, as increasing dose and duration can improve efficacy [26]. Many efforts have been made to optimize the BQT. Possibly, the most effective BQT is the one employing the highest practical doses of the single drugs for the longest reasonable duration, such as 14 days. A one-arm, open-label pilot study of $47 \mathrm{H}$. pylori-infected, asymptomatic/mildly dyspeptic adult Hispanic residents of El Paso, Texas showed a per-protocol effectiveness of $97.7 \%$ for BQT given for 14 days [34]. In this study the combination capsule of bismuth, metronidazole, and tetracycline (daily doses: 1,680, 1,500, and 1,500 mg, respectively) plus omeprazole (daily dose: $40 \mathrm{mg}$ ) was used. Unfortunately, only one of the trials included in our meta-analysis evaluated the BQT for 14 days, without employing the highest practical doses of the single drugs. Thus, the heterogeneity in the treatment regimens included in the present analysis does not allow for the recommendation of an 'optimal' BQT. Only 2 RCTs were available for the subgroup
40

Digestion 2013;88:33-45

DOI: $10.1159 / 000350719$
Venerito/Krieger/Ecker/Leandro/ Malfertheiner 
analysis comparing the 10-day BQT versus the 7-day CTT.

In conclusion, on the basis of our analysis, the 10-day BQT is more effective than the 7-day CTT as a first-line therapy for $H$. pylori infection, whereas BQT and CTT, both taken for 7 or 10 days, yielded similar eradication rates. BQT is independent of clarithromycin resistance and is at all only minimally affected by metronidazole resistance. Compliance rates and side effects were comparable for both treatment regimens.

\section{Disclosure Statement}

Peter Malfertheiner, MD is the guarantor of the article. No funding was received for the preparation of this manuscript. Marino Venerito has no conflicts of interest relevant to this study. Tina Krieger received honoraria from Aptalis Pharma. Thomas Ecker received honoraria from Aptalis Pharma. Gioacchino Leandro has no conflicts of interest relevant to this study. Peter Malfertheiner received honoraria from Aptalis Pharma, Abbott, AstraZeneca, and Takeda.

\section{Appendix}

Appendix Table 1. Study characteristics

\begin{tabular}{|c|c|c|c|c|}
\hline Author & Patient characteristics & $\begin{array}{l}\text { Diagnosis of } H \text {. pylori } \\
\text { infection for inclusion } \\
\text { in the study }\end{array}$ & Exclusion criteria & $\begin{array}{l}\text { H. pylori diagnostic after } \\
\text { eradication therapy }\end{array}$ \\
\hline $\begin{array}{l}\text { Gomollon } \\
\text { et al. [8] }\end{array}$ & $\begin{array}{l}\text { H. pylori-positive } \\
\text { patients with endo- } \\
\text { scopically proven } \\
\text { peptic ulcer disease, } \\
\text { age between } 18 \text { and } \\
80 \text { years }\end{array}$ & $\begin{array}{l}\text { patients were enrolled } \\
\text { if both RUT and } \\
\text { histology were positive }\end{array}$ & $\begin{array}{l}\text { pregnancy, allergy to any study medications, chronic } \\
\text { ingestion of NSAIDs, severe esophagitis, gastric cancer, } \\
\text { severe GI bleeding in the previous } 6 \text { months, previous } \\
\text { H. pylori treatment }\end{array}$ & $\begin{array}{l}{ }^{13} \mathrm{C} \text {-UBT or biopsy-based } \\
\text { testing at } 8 \text { weeks after } \\
\text { treatment }\end{array}$ \\
\hline $\begin{array}{l}\text { Calvet } \\
\text { et al. [9] }\end{array}$ & $\begin{array}{l}\text { H. pylori-positive } \\
\text { patients with endoscop- } \\
\text { ically proven peptic } \\
\text { ulcer disease, age } 18 \\
\text { years or older }\end{array}$ & $\begin{array}{l}\text { patients were enrolled } \\
\text { if }{ }^{13} \mathrm{C}-\mathrm{UBT}, \mathrm{RUT} \text {, or } \\
\text { histology was positive }\end{array}$ & $\begin{array}{l}\text { inability to attend follow-up, previously failed eradication } \\
\text { therapy, treatment with antibiotics during the } 4 \text { weeks prior } \\
\text { to the study, and previous ulcer surgery }\end{array}$ & $\begin{array}{l}{ }^{13} \mathrm{C} \text {-UBT or biopsy-based } \\
\text { testing at least } 2 \text { months } \\
\text { after treatment }\end{array}$ \\
\hline $\begin{array}{l}\text { Katelaris } \\
\text { et al. }[10]\end{array}$ & $\begin{array}{l}\text { H. pylori-positive } \\
\text { patients with dyspepsia } \\
\text { and no evidence of } \\
\text { peptic ulcer disease or } \\
\text { esophagitis at endos- } \\
\text { copy, age } 18 \text { years or } \\
\text { older }\end{array}$ & $\begin{array}{l}\text { patients were enrolled } \\
\text { if the RUT was posi- } \\
\text { tive; confirmatory test: } \\
\text { histology and }{ }^{13} \mathrm{C}- \\
\text { UBT }\end{array}$ & $\begin{array}{l}\text { previous } H \text {. pylori treatment or concomitant or recent } \\
\text { (within } 30 \text { days) use of PPIs, antibiotics, bismuth salts, or } \\
\text { NSAIDs }\end{array}$ & $\begin{array}{l}{ }^{13} \mathrm{C}-\mathrm{UBT} \text { at } 8 \text { weeks after } \\
\text { treatment }\end{array}$ \\
\hline $\begin{array}{l}\text { Mantzaris } \\
\text { et al. }[11]\end{array}$ & $\begin{array}{l}\text { H. pylori-positive } \\
\text { patients with endoscop- } \\
\text { ically proven active } \\
\text { duodenal ulcer }\end{array}$ & $\begin{array}{l}\text { patients were enrolled } \\
\text { if the RUT was posi- } \\
\text { tive; confirmatory test: } \\
\text { histology }\end{array}$ & $\begin{array}{l}\text { chronic alcoholism, chronic renal or hepatic failure, } \\
\text { malignant disease, previous gastric surgery, treatment with } \\
\text { anticoagulants, treatment with antibiotics during the } \\
\text { month preceding study entry, and allergy to any study } \\
\text { medications }\end{array}$ & $\begin{array}{l}\text { HUT, histology and } \\
\text { immunohistochemistry } \\
\text { performed 10-12 weeks } \\
\text { after treatment }\end{array}$ \\
\hline $\begin{array}{l}\text { Laine } \\
\text { et al. [12] }\end{array}$ & $\begin{array}{l}\text { H. pylori-positive } \\
\text { patients with active } \\
\text { duodenal ulcer at base- } \\
\text { line endoscopy or a } \\
\text { history of duodenal } \\
\text { ulcer (within the last } 5 \\
\text { years) documented by } \\
\text { endoscopy or radiology }\end{array}$ & $\begin{array}{l}\text { patients were enrolled } \\
\text { if }{ }^{13} \mathrm{C} \text {-UBT plus histol- } \\
\text { ogy and/or culture } \\
\text { were positive }\end{array}$ & $\begin{array}{l}\text { upper GI bleeding within the past month, prior } H \text {. pylori } \\
\text { treatment, use of antibiotics or bismuth in the prior } 30 \\
\text { days, regular use of a PPI in the } 15 \text { days or of an } \mathrm{H}_{2^{-}} \\
\text {receptor antagonist, sucralfate, or misoprostol in the } 7 \text { days } \\
\text { before baseline, chronic use of NSAIDs (except for aspirin } \\
325 \mathrm{mg} / \text { day), contraindication to use of study medications, } \\
\text { pregnancy or lactation, other serious medical conditions, or } \\
\text { clinically significant laboratory abnormalities at baseline }\end{array}$ & $\begin{array}{l}2 \text { negative }{ }^{13} \mathrm{C}-\mathrm{UBT} \text { s } \\
\text { performed at least } 29 \text { and } \\
57 \text { days after treatment }\end{array}$ \\
\hline $\begin{array}{l}\text { Pai } \\
\text { et al. [13] }\end{array}$ & $\begin{array}{l}\text { H. pylori-positive } \\
\text { patients with endoscop- } \\
\text { ically proven active or } \\
\text { healed peptic ulcers }\end{array}$ & $\begin{array}{l}\text { patients were enrolled } \\
\text { if both RUT and } \\
\text { histology were positive }\end{array}$ & $\begin{array}{l}\text { peptic ulcer complications, recent (within } 2 \text { weeks) use of } \\
\text { PPIs, antibiotics, or bismuth salts }\end{array}$ & $\begin{array}{l}\text { biopsy-based test per- } \\
\text { formed } 30 \text { days after treat- } \\
\text { ment }\end{array}$ \\
\hline
\end{tabular}




\begin{tabular}{|c|c|c|c|c|}
\hline Author & Patient characteristics & $\begin{array}{l}\text { Diagnosis of } H \text {. pylori } \\
\text { infection for inclusion } \\
\text { in the study }\end{array}$ & Exclusion criteria & $\begin{array}{l}\text { H. pylori diagnostic after } \\
\text { eradication therapy }\end{array}$ \\
\hline $\begin{array}{l}\text { Jang } \\
\text { et al. [14] }\end{array}$ & $\begin{array}{l}\text { H. pylori-positive } \\
\text { patients with peptic } \\
\text { ulcer disease }\end{array}$ & $\begin{array}{l}\text { patients were enrolled } \\
\text { if both RUT and } \\
\text { histology were positive }\end{array}$ & exclusion criteria not extractable, article in Korean & $\begin{array}{l}{ }^{13} \mathrm{C}-\mathrm{UBT} \text { performed } \\
4-6 \text { weeks after treatment }\end{array}$ \\
\hline $\begin{array}{l}\text { Uygun } \\
\text { et al. [15] }\end{array}$ & $\begin{array}{l}\text { H. pylori-positive } \\
\text { patients with nonulcer } \\
\text { dyspepsia }\end{array}$ & $\begin{array}{l}\text { patients were enrolled } \\
\text { if both RUT and } \\
\text { histology were positive }\end{array}$ & $\begin{array}{l}\text { pregnancy; lactation; age }<18 \text { years; previous } H \text {. pylori } \\
\text { treatment; consumption of PPIs, } \mathrm{H}_{2} \text {-receptor blockers, } \\
\text { NSAIDs, bismuth salts, or antibiotics in the previous } \\
4 \text { weeks before enrollment; previous gastric surgery; } \\
\text { presence of liver dysfunction or renal failure; alcohol abuse, } \\
\text { and known allergy to the prescribed antibiotics }\end{array}$ & $\begin{array}{l}{ }^{13} \mathrm{C} \text {-UBT performed } 6 \\
\text { weeks after treatment }\end{array}$ \\
\hline $\begin{array}{l}\text { Ching } \\
\text { et al. [16] }\end{array}$ & $\begin{array}{l}\text { H. pylori-positive } \\
\text { patients with dyspeptic } \\
\text { symptoms and a recent } \\
\text { endoscopy showing } \\
\text { peptic ulcers or gastritis }\end{array}$ & $\begin{array}{l}\text { patients were enrolled } \\
\text { if histology and cul- } \\
\text { ture, RUT or }{ }^{13} \mathrm{C} \text {-UBT } \\
\text { was positive }\end{array}$ & $\begin{array}{l}\text { age less than } 18 \text { or above } 75 \text { years, symptomatic gallstones, } \\
\text { treated with antibiotic or bismuth-containing drugs during } \\
\text { the month prior to inclusion, treated with PPIs during the } \\
\text { week prior to inclusion, disturbed GI physiology (gastric } \\
\text { surgery, vagotomy, Zollinger-Ellison syndrome, chronic } \\
\text { ingestion of NSAIDs), concomitant serious disease, } \\
\text { concomitant medications that may adversely interact with } \\
\text { the study drugs (e.g. warfarin, antiepileptics), pregnancy } \\
\text { and breast-feeding, childbearing age without adequate } \\
\text { contraception, allergy to drugs used in the study, mental } \\
\text { illness, and heavy drinking or abuse of drugs }\end{array}$ & $\begin{array}{l}{ }^{13} \mathrm{C} \text {-UBT performed at } 8 \\
\text { weeks after treatment }\end{array}$ \\
\hline $\begin{array}{l}\text { Songür } \\
\text { et al. [17] }\end{array}$ & $\begin{array}{l}\text { H. pylori-positive } \\
\text { patients with dyspeptic } \\
\text { symptoms }\end{array}$ & $\begin{array}{l}\text { patients were enrolled } \\
\text { if }{ }^{13} \mathrm{C} \text {-UBT or histol- } \\
\text { ogy was positive }\end{array}$ & $\begin{array}{l}\text { previous } H \text {. pylori treatment therapy; treatment with } \\
\text { NSAIDs, PPIs, } \mathrm{H}_{2} \text {-receptor blockers, or antimicrobials } \\
\text { within the previous } 4 \text { weeks, pregnancy; history of allergy to } \\
\text { penicillin or any antibiotic, and previous gastric surgery }\end{array}$ & $\begin{array}{l}{ }^{13} \mathrm{C}-\mathrm{UBT} \text { performed at } \\
6 \text { weeks after treatment }\end{array}$ \\
\hline $\begin{array}{l}\text { Zheng } \\
\text { et al. [18] }\end{array}$ & $\begin{array}{l}\text { H. pylori-positive } \\
\text { patients with nonulcer } \\
\text { dyspepsia, age between } \\
18 \text { and } 70 \text { years }\end{array}$ & $\begin{array}{l}\text { patients were enrolled } \\
\text { if both }{ }^{13} \mathrm{C} \text {-UBT and } \\
\text { histology were positive }\end{array}$ & $\begin{array}{l}\text { previous } H \text {. pylori treatment therapy, treatment with PPIs, } \\
\mathrm{H}_{2} \text {-receptor blockers, bismuth or antimicrobials within the } \\
\text { previous } 4 \text { weeks, pregnancy or lactating, history of allergy } \\
\text { to penicillin or any antibiotic used in the study, duodenal or } \\
\text { gastric ulcer, a severe heart condition, hepatic or renal } \\
\text { diseases, and previous gastric surgery }\end{array}$ & $\begin{array}{l}{ }^{13} \mathrm{C}-\mathrm{UBT} \text { performed at } \\
\text { least } 4 \text { weeks after treat- } \\
\text { ment. }\end{array}$ \\
\hline $\begin{array}{l}\text { Malfertheiner } \\
\text { et al. [19] }\end{array}$ & $\begin{array}{l}\text { H. pylori-positive } \\
\text { patients with upper GI } \\
\text { symptoms, age } 18 \text { years } \\
\text { or older }\end{array}$ & $\begin{array}{l}\text { H. pylori infection } \\
\text { confirmed by both } \\
{ }^{13} \text { C-UBT and RUT; } \\
\text { confirmatory test: } \\
\text { histology, culture, or } \\
\text { PCR }\end{array}$ & $\begin{array}{l}\text { previous } H \text {. pylori treatment therapy, contraindications to } \\
\text { study drugs, substantial organ impairment, severe or } \\
\text { unstable cardiopulmonary or endocrine disease, history of } \\
\text { surgery of the upper GI tract, evidence of bleeding or iron- } \\
\text { deficiency anemia, Barrett's esophagus or high-grade } \\
\text { dysplasia, dysphagia, history of malignancy, history of drug } \\
\text { or alcohol misuse within } 1 \text { year of the trial, continuously } \\
\text { used antiulcer drugs (including PPIs during the } 2 \text { weeks } \\
\text { before the }{ }^{13} \mathrm{C} \text {-UBT), antibiotics or bismuth compounds } \\
\text { (more than } 3 \text { times per week, } 1 \text { month before screening), } \\
\text { systemic glucocorticoids, NSAIDs, or anticoagulation or } \\
\text { platelet aggregation inhibitors (except acetylsalicylic acid } \\
\leq 100 \text { mg per day) }\end{array}$ & $\begin{array}{l}2 \text { negative }{ }^{13} \mathrm{C} \text {-UBTs } \\
\text { performed at least } 28 \text { and } \\
56 \text { days after treatment }\end{array}$ \\
\hline
\end{tabular}

$\mathrm{UBT}=$ Urea breath test $\mathrm{RUT}=$ rapid urease test; NSAIDs = nonsteroidal anti-inflammatory drugs. 


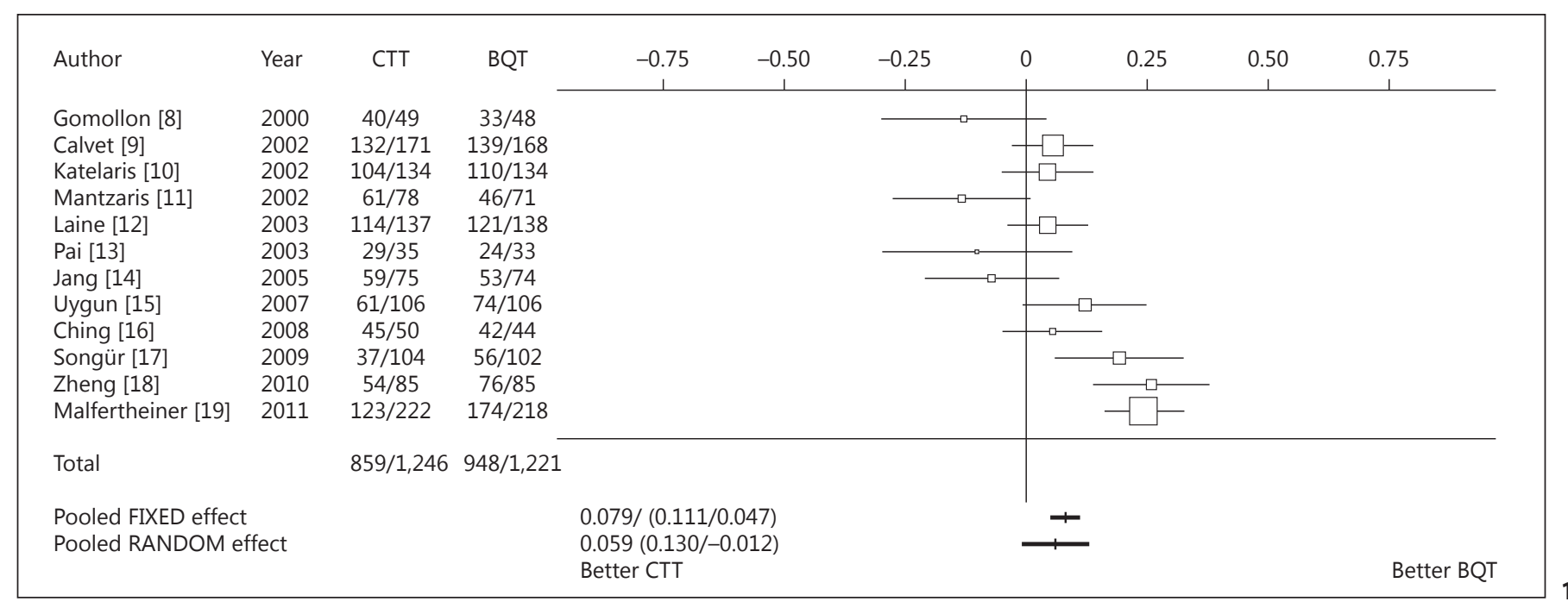

Appendix figure 1. Forest plot of BQT vs. CTT. RD with 95\% CI is shown on the right side of the figure.

Appendix figure 2. Test for asymmetry of the funnel plot.

Appendix figure 3. Forest plot of BQT vs. CTT; subgroup analysis according to location: Eastern and Western hemispheres. RD with $95 \%$ CI is shown on the right side of the figure. REM = Randomeffects model; FEM = fixedeffects model.

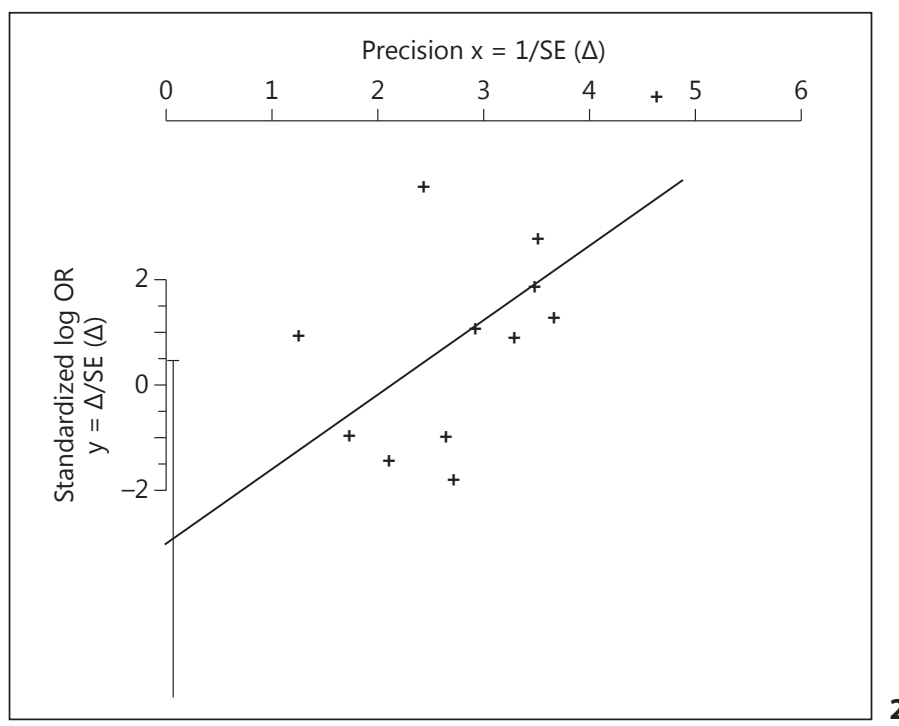

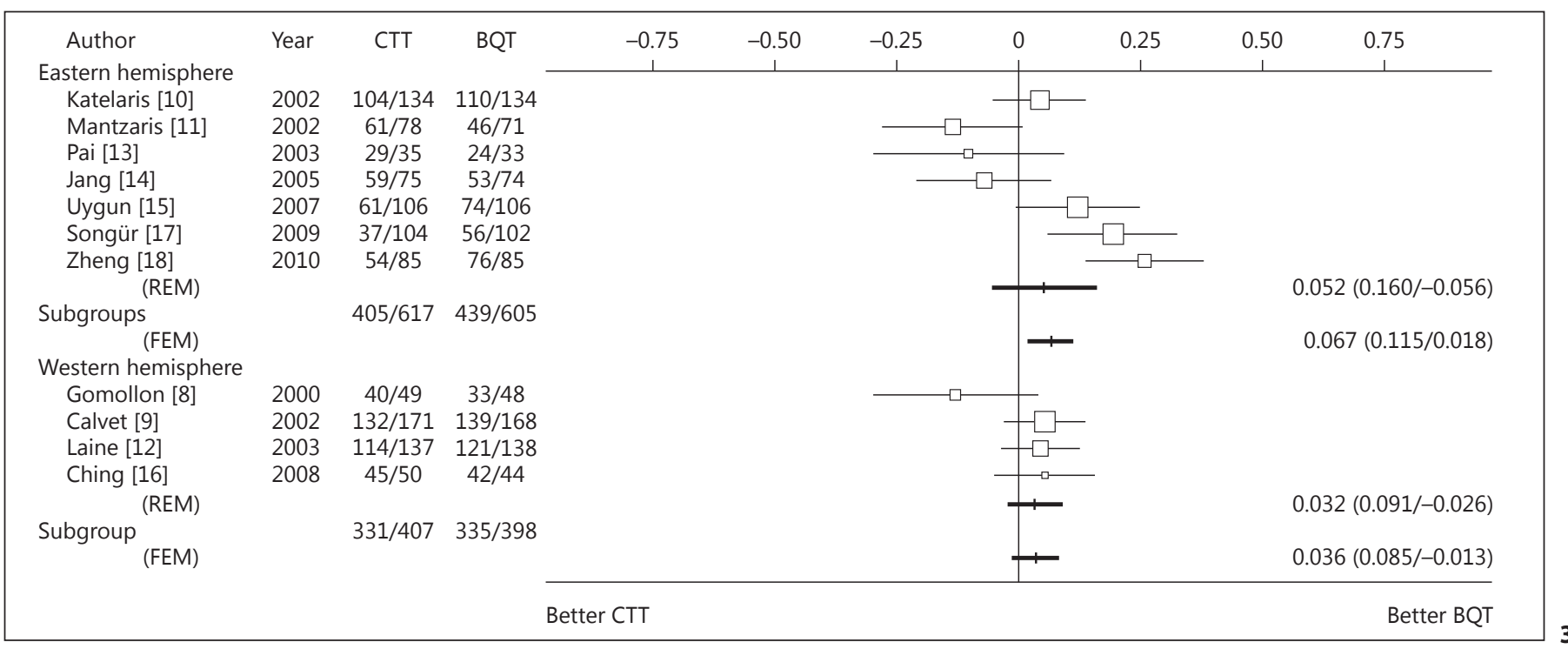

Quadruple vs. Triple Therapy for H. pylori Eradication 


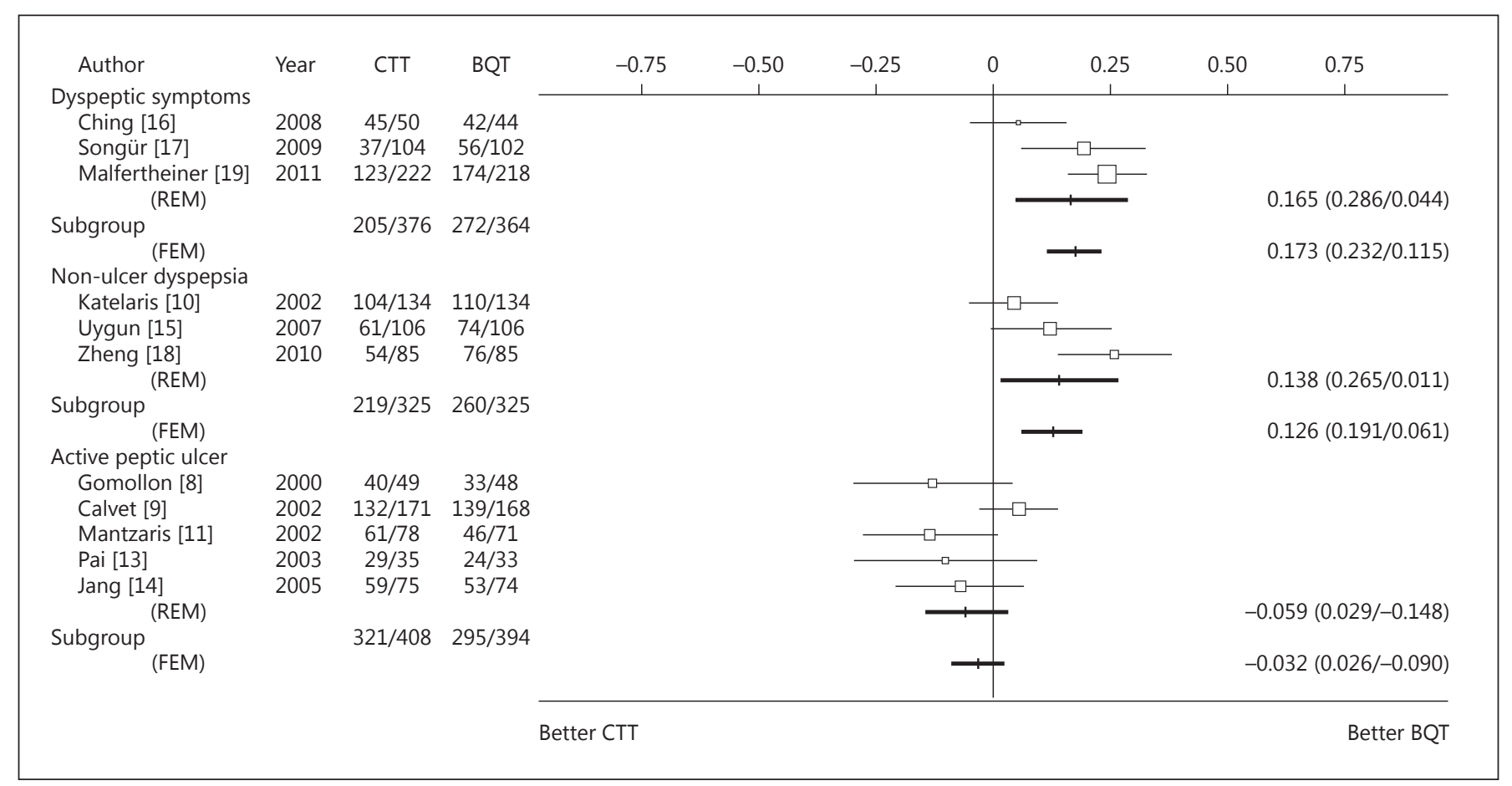

Appendix figure 4. Forest plot of BQT vs. CTT; subgroup analysis according to treatment indication: dyspeptic symptoms, nonulcer dyspepsia and active peptic ulcer. RD with $95 \% \mathrm{CI}$ is shown on the right side of the figure.

\section{References}

1 Nagini S: Carcinoma of the stomach: a review of epidemiology, pathogenesis, molecular genetics and chemoprevention. World J Gastrointest Oncol 2012;4:156-169.

-2 Malfertheiner P, Megraud F, O'Morain CA, Atherton J, Axon AT, Bazzoli F, et al: Management of Helicobacter pylori infection - the Maastricht IV/Florence Consensus Report. Gut 2012;61:646-664.

3 Glupczynski Y, Megraud F, Lopez-Brea M, Andersen LP: European multicentre survey of in vitro antimicrobial resistance in Helicobacter pylori. Eur J Clin Microbiol Infect Dis 2001;20:820-823.

-4 Megraud F, Coenen S, Versporten A, Kist M, Lopez-Brea M, Hirschl AM, et al: Helicobacter pylori resistance to antibiotics in Europe and its relationship to antibiotic consumption. Gut 2013;62:34-42.

5 Gene E, Calvet X, Azagra R, Gisbert JP: Triple vs. quadruple therapy for treating Helicobacter pylori infection: a meta-analysis. Aliment Pharmacol Ther 2003;17:1137-1143.

6 Luther J, Higgins PD, Schoenfeld PS, Moayyedi P, Vakil N, Chey WD: Empiric quadruple vs. triple therapy for primary treatment of $\mathrm{He}$ licobacter pylori infection: systematic review and meta-analysis of efficacy and tolerability. Am J Gastroenterol 2010;105:65-73.
7 Leandro G: Meta-Analysis in Medical Research: The Handbook for the Understanding and Practice of Meta-Analysis (with software). Malden, BMJ Books, 2005.

8 Gomollon F, Valdeperez J, Garuz R, Fuentes J, Barrera F, Malo J, et al: Cost-effectiveness analysis of 2 strategies of Helicobacter pylori eradication: results of a prospective and randomized study in primary care. Medicina Clinica 2000;115:1-6.

-9 Calvet X, Ducons J, Guardiola J, Tito L, Andreu V, Bory F, et al: One-week triple vs. quadruple therapy for Helicobacter pylori infection - a randomized trial. Aliment Pharmacol Ther 2002;16:1261-1267.

10 Katelaris PH, Forbes GM, Talley NJ, Crotty B: A randomized comparison of quadruple and triple therapies for Helicobacter pylori eradication: The QUADRATE Study. Gastroenterology 2002;123:1763-1769.

11 Mantzaris GJ, Petraki K, Archavlis E, Amberiadis $\mathrm{P}$, Christoforidis $\mathrm{P}$, Kourtessas D, et al: Omeprazole triple therapy versus omeprazole quadruple therapy for healing duodenal ulcer and eradication of Helicobacter pylori infection: a 24-month follow-up study. Eur J Gastroenterol Hepatol 2002;14:1237-1243.
12 Laine L, Hunt R, El-Zimaity H, Nguyen B, Osato M, Spenard J: Bismuth-based quadruple therapy using a single capsule of bismuth biskalcitrate, metronidazole, and tetracycline given with omeprazole versus omeprazole, amoxicillin, and clarithromycin for eradication of Helicobacter pylori in duodenal ulcer patients: a prospective, randomized, multicenter, North American trial. Am J Gastroenterol 2003;98:562-567.

13 Pai CG, Thomas CP, Biswas A, Rao S, Ramnarayan K: Quadruple therapy for initial eradication of Helicobacter pylori in peptic ulcer: comparison with triple therapy. Indian J Gastroenterol 2003;22:85-87.

14 Jang HJ, Choi MH, Kim YS, Seo YA, Baik KH, Baik IH, et al: Effectiveness of triple therapy and quadruple therapy for Helicobacter pylori eradication (in Korean). Korean J Gastroenterol 2005;46:368-372.

15 Uygun A, Kadayifci A, Safali M, Ilgan S, Bagci S: The efficacy of bismuth containing quadruple therapy as a first-line treatment option for Helicobacter pylori. J Dig Dis 2007;8:211215 . 
16 Ching SS, Sabanathan S, Jenkinson LR: Treatment of Helicobacter pylori in surgical practice: a randomised trial of triple versus quadruple therapy in a rural district general hospital. World J Gastroenterol 2008; 14 : 3855-3860.

-17 Songür Y, Senol A, Balkarli A, Basturk A, Cerci S: Triple or quadruple tetracycline-based therapies versus standard triple treatment for Helicobacter pylori treatment. Am J Med Sci 2009;338:50-53.

18 Zheng Q, Chen WJ, Lu H, Sun QJ, Xiao SD: Comparison of the efficacy of triple versus quadruple therapy on the eradication of Helicobacter pylori and antibiotic resistance. J Dig Dis 2010;11:313-318.

19 Malfertheiner P, Bazzoli F, Delchier JC, Celinski K, Giguere M, Riviere M, et al: Helicobacter pylori eradication with a capsule containing bismuth subcitrate potassium, metronidazole, and tetracycline given with omeprazole versus clarithromycin-based triple therapy: a randomised, open-label, noninferiority, phase 3 trial. Lancet 2011;377: 905-913.

-20 Singh V, Mishra S, Maurya P, Rao G, Jain AK, Dixit VK, et al: Drug resistance pattern and clonality in $H$. pylori strains. J Infect Dev Ctries, 2009;3:130-136.

21 Chung JW, Lee GH, Jeong JY, Lee SM, Jung $\mathrm{JH}$, Choi KD, et al: Resistance of Helicobacter pylori strains to antibiotics in Korea with a focus on fluoroquinolone resistance. J Gastroenterol Hepatol 2012;27:493-497.
22 Onder G, Aydin A, Akarca U, Tekin F, Ozutemiz O, Ilter T: High Helicobacter pylori resistance rate to clarithromycin in Turkey. J Clin Gastroenterol 2007;41:747-750.

-23 Fuccio L, Minardi ME, Zagari RM, Grilli D, Magrini N, Bazzoli F: Meta-analysis: duration of first-line proton-pump inhibitor based triple therapy for Helicobacter pylori eradication. Ann Intern Med 2007;147:553-562.

24 Jadad AR, Moore RA, Carroll D, Jenkinson C, Reynolds DJ, Gavaghan DJ, et al: Assessing the quality of reports of randomized clinical trials: is blinding necessary? Control Clin Trials $1996 ; 17: 1-12$

25 Zagari RM, Bianchi-Porro G, Fiocca R, Gasbarrini G, Roda E, Bazzoli F: Comparison of 1 and 2 weeks of omeprazole, amoxicillin and clarithromycin treatment for Helicobacter pylori eradication: the HYPER Study. Gut 2007; 56:475-479.

26 Rimbara E, Fischbach LA, Graham DY: Optimal therapy for Helicobacter pylori infections. Nat Rev Gastroenterol Hepatol 2011;8:79-88.

27 Chey WD, Wong BC: American College of Gastroenterology guideline on the management of Helicobacter pylori infection. Am J Gastroenterol 2007;102:1808-1825.
28 Fock KM, Katelaris P, Sugano K, Ang TL, Hunt R, Talley NJ, et al: Second Asia-Pacific Consensus Guidelines for Helicobacter pylori infection. J Gastroenterol Hepatol 2009;24: 1587-1600.

29 Asaka M, Kato M, Takahashi S, Fukuda Y, Sugiyama T, Ota $\mathrm{H}$, et al: Guidelines for the management of Helicobacter pylori infection in Japan: 2009 revised edition. Helicobacter 2010;15:1-20.

30 de Boer WA: Bismuth triple therapy: still a very important drug regimen for curing Helicobacter pylori infection. Eur J Gastroenterol Hepatol 1999;11:697-700.

31 van der Wouden EJ, Thijs JC, van Zwet AA, Sluiter WJ, Kleibeuker JH: The influence of in vitro nitroimidazole resistance on the efficacy of nitroimidazole-containing anti-Helicobacter pylori regimens: a meta-analysis. Am J Gastroenterol 1999;94:1751-1759.

32 Graham DY, Fischbach L: Helicobacter pylori treatment in the era of increasing antibiotic resistance. Gut 2010;59:1143-1153.

33 Megraud F, Broutet N: Epidemiologie des maladies infectieuses en France en 1997. Surveillance de la resistance aux antibiotiques. Bull Epidemiol Ann 1999:187-188.

- 34 Salazar CO, Cardenas VM, Reddy RK, Dominguez DC, Snyder LK, Graham DY: Greater than $95 \%$ success with 14 -day bismuth quadruple anti-Helicobacter pylori therapy: a pilot study in US Hispanics. Helicobacter 2012;17:382-390.
Quadruple vs. Triple Therapy for H. pylori Eradication 